Jurnal Akuntansi dan Keuangan (JAK)

Volume 5, Nomor 2 Tahun 2020

Page: 318 - 328

http://ojs.uho.ac.id/index.php/jak-uho

e-ISSN: 2088-4656

\title{
ANALISIS EFEKTIFITAS E-SYSTEM UNTUK MENINGKATKAN KEPATUHAN WAJIB PAJAK ORANG PRIBADI DALAM MENYAMPAIKAN SPT TAHUNAN (STUDI PADA KANTOR PELAYANAN PAJAK PRATAMA KENDARI)
}

Oleh :

\author{
Ishak Awaluddin ${ }^{1}$, Ulvy Restiana Parintak ${ }^{2}$ \\ Email : ulvirestianaparintak@gmail.com
}

\begin{abstract}
ABSTRAK
Penelitian ini bertujuan untuk mengetahui efektifitas dan peran e-System perpajakan dalam meningkatkan kepatuhan wajib pajak. Teknik pengumpulan data dalam penelitian ini yaitu kuisioner, wawancara dan dokumentasi dengan menggunakan analisis deskriptif. Hasil Penelitian menunjukkan bahwa efektifitas e-System perpajakan berupa e-SPT di KPP Pratama Kendari pada tahun 2020 telah dikategorikan efektif, yang artinya aplikasi e-SPT sudah diterapkan dengan baik sehingga mempermudah Wajib Pajak dalam melakukan pengisian SPT Tahunan secara elektronik. Sedangkan efektifitas e-System berupa e-Filing pada tahun 2020 juga telah dikategorikan sangat efektif, yang berarti media e-Filing sangat membantu wajib pajak dalam melaporkan SPT Tahunan disebabkan media e-Filing bersifat online dan real time selain itu jumlah pelaporan SPT sangat meningkat dengan adanya media e-Filing dibandingkan dengan sistem pelaporan secara manual. Sehingga dengan meningkatnya efektifitas e-System Perpajakan, tingkat kepatuhan wajib pajak juga telah dikategorikan sangat patuh, disebabkan Wajib Pajak telah melaksanakan kewajiban perpajakannya secara maksimal.
\end{abstract}

Kata kunci : E-system Perpajakan, e-SPT, e-Filing, Kepatuhan, WPOP

\section{ABSTRACT}

This study aims to determine the effectiveness and role of taxation of the electronic system in enhancing taxpayer compliance. The methods of data collection in this study were questionnaires, interviews, and documentation using descriptive analysis. The results showed that the tax efficiency of the electronic system in the form of an e-SPT in the Kendari General Tax Administration was classified as effective in 2020, which means that the e-SPT application was implemented properly, which made it easier for taxpayers to fill out annual tax returns electronically. While the effectiveness of the electronic system in the form of an electronic archive in 2020 was also classified as very effective, this means that electronic electronic media is very useful for taxpayers in reporting annual tax returns, since electronic electronic media are online and in real time. In addition, the number of SPT reports is significantly increased by the availability of an electronic archive compared to manual reporting systems. So with the increasing efficiency of the electronic taxation system, the level of compliance of taxpayers was also categorized as very relevant, since the taxpayer fulfilled his tax obligations to the maximum.

Keywords : Taxation e-System, e-SPT, e-Filing, Compliance, Individual Taxpayer

\section{PENDAHULUAN}

Pajak merupakan kontribusi wajib rakyat kepada negara yang terutang, baik sebagai orang pribadi atau badan usaha yang bersifat memaksa berdasarkan UndangUndang, dengan tidak mendapatkan imbalan secara langsung dan digunakan untuk keperluan negara baik sebesar-besarnya kemakmuran rakyat. Pembayaran pajak merupakan perwujudan kewajiban dan peran serta Wajib Pajak untuk ikut secara 
langsung dan bersama-sama melaksanakan pembiayaan negara dan pembangunan nasional. Sebagai salah satu sumber penerimaan negara terbesar, penerimaan pajak ini berperan dalam kesejahteraan masyarakat Indonesia. sehingga Indonesia akan kesulitan untuk berkembang jika pajak yang didapatkan jauh dari realisasi penerimaan.

Pemerintah meningkatkan penerimaan di sektor pajak di mulai pada tahun 1983 melalui reformasi perpajakan. Perubahan paling mendasar dari reformasi ini adalah perubahan sistem pemungutan pajak dari Official Asssesment System menjadi Self Assesment system. Self Assesment system adalah suatu sistem dimana Wajib Pajak bertanggung jawab terhadap kewajiban dalam perhitungan, pelaporan dan pembayaran pajak yang terutang kepada pemerintah. Kesadaran dan kepatuhan Wajib Pajak sangat diperlukan dalam perkembangan perpajakan di Indonesia, guna meningkatkan efektifitas dan efisiensi penerimaan pajak yang diinginkan. Berkaitan dengan hal tersebut, maka Direktorat Jenderal Pajak melakukan reformasi kebijakan seperti penggunaan e-System dalam pelaporannya.

Sistem perpajakan yang semula manual dinilai masih memiliki banyak kelemahan khususnya bagi Wajib Pajak dalam memenuhi kewajibannya, seperti Wajib Pajak yang memiliki transaksi cukup besar dalam pelaporan SPT diharuskan untuk melampirkan dokumen-dokumen (hardcopy) dalam jumlah yang cukup banyak untuk diserahkan ke Kantor Pelayanan Pajak (KPP). Selain itu, waktu yang cukup lama sehingga pelaporan SPT menjadi tertunda dan bahkan terlambat sehingga dapat menimbulkan sanksi denda akibat keterlambatan pelaporan tersebut. Kelemahan lain dalam sistem manual adalah kesalahan pada manusia (human error) dalam proses rekapan ulang data oleh fiskus. Kebutuhan akan teknologi yang semakin tinggi dan menunutut membuat orang mulai mempelajari dan mengikuti perkembangan teknologi informasi.

Direktorat Jenderal Pajak dalam rangka mempermudah Wajib Pajak untuk melaporkan pajak menerbitkan Peraturan Dirjen Pajak Nomor PER-02/PJ/2019 Tentang tata Cara Penyampaian, Penerimaan, dan Pengolahan SPT yang merupakan pelaksanaan dari Peraturan Menteri Keuangan Nomor 9/PMK.03/2018, dengan menggunakan teknologi informasi yang juga mengikuti kemajuan teknologi dengan pelayanan berbasis e-System seperti e-SPT dan e-Filing, yang diharapkan dapat meningkatkan mekanisme kontrol dan pelaporan yang lebih efektif. Tujuan di perbaharuinya e-System perpajakan ini dibuat dengan harapan dapat mempermudah Wajib Pajak untuk melaksanakan kewajiban perpajakannya. Hal ini tidak sebanding dengan Laporan Kinerja Direktorat Jenderal Pajak tahun 2017, ada sebanyak 36.031.972 Wajib Pajak yang terdaftar di Indonesia dengan 16.599.632 Wajib Pajak menyampaikan SPT dan hanya 4.762.217 orang yang menyampaikan SPT melalui sistem elektronik dengan eFiling. Hal ini berarti Wajib Pajak yang menggunakan sistem elektronik menggunakan efiling tidak mencapai 50\% dari jumlah Wajib Pajak efektif.

Berdasarkan Laporan Kinerja Direktorat Jenderal Pajak tahun 2017, ada sebanyak 36.031.972 Wajib Pajak yang terdaftar di Indonesia dengan 16.599.632 Wajib Pajak menyampaikan SPT dan hanya 4.762 .217 orang yang menyampaikan SPT melalui sistem elektronik dengan e-Filing. Hal ini berarti Wajib Pajak yang menggunakan sistem elektronik menggunakan e-filing tidak mencapai 50\% dari jumlah Wajib Pajak efektif.

Selain itu peneliti menampilkan Jumlah penggunaan e-system berupa e-SPT dan e-Filing serta data Jumlah Wajib Pajak Orang Pribadi pada tahun 2014 sampai dengan 2018 di KPP Pratama Kendari sebagai berikut : 


\section{Tabel 1.1}

\section{Jumlah Wajib Pajak Orang Pribadi Terdaftar dan target Pengguna e-SPT dan e-} Filing

\begin{tabular}{|c|c|c|c|c|c|}
\hline \multirow{3}{*}{ Tahun } & \multirow{2}{*}{$\begin{array}{c}\text { Jumlah } \\
\text { Werdaftar }\end{array}$} & \multicolumn{4}{|c|}{ Target dan Realisasi WPOP Pengguna E- } \\
\cline { 3 - 6 } & $\begin{array}{c}\text { System dalam menyampaikan SPT Tahunan } \\
\text { penggun } \\
\text { a e-SPT }\end{array}$ & $\begin{array}{c}\text { Realisasi } \\
\text { Pengguna } \\
\text { e-SPT }\end{array}$ & $\begin{array}{c}\text { Target } \\
\text { pengguna } \\
\text { e-Filing }\end{array}$ & $\begin{array}{c}\text { Realisasi } \\
\text { Pengguna } \\
\text { e-Filing }\end{array}$ \\
\hline 2014 & 98.509 & 2.648 & 743 & 5.281 & 4.061 \\
\hline 2015 & 110.631 & 4.554 & 1.558 & 7.256 & 6.411 \\
\hline 2016 & 125.348 & 12.552 & 5.463 & 34.425 & 31.692 \\
\hline 2017 & 137.236 & 17.407 & 7.799 & 48.532 & 45.132 \\
\hline 2018 & 151.608 & 18.942 & 8.681 & 49.005 & 45.608 \\
\hline
\end{tabular}

Sumber: KPP Pratama Kendari, 2020

Dari data tersebut dapat dilihat bahwa penggunaan e-System yaitu e-SPT dan eFiling oleh Wajib Pajak Orang Pribadi (WPOP) di KPP Pratama Kendari belum mencapai setengah dari jumlah Wajib Pajak yang terdaftar dan belum mencapai target penggunaan e-System tersebut. Hal ini dikarenakan beberapa Wajib Pajak yang belum mengetahui arti pentingnya pajak dan menganggap pelaporan SPT menggunakan e-System rumit dan membingungkan dikarenakan Wajib Pajak juga tidak paham pengoperasian aplikasi dari e-System yang berbasis elektronik dan menggunakan komputer.

Tujuan dalam penelitian ini yaitu Untuk mengetahui dan menganalisis efektifitas e-System Perpajakan di Kantor Pelayanan Pajak Pratama Kendari dan Untuk mengetahui dan menganalisis e-System dalam meningkatkan kepatuhan Wajib Pajak Orang Pribadi dalam melaporkan SPT Tahunan orang pribadi di Kantor Pelayanan Pajak Pratama Kendari.

\section{Definisi Pajak}

\section{LANDASAN TEORI}

Menurut Undang-Undang Nomor 16 tahun 2009 tentang perubahan ke empat atas Undang-Undang Nomor 6 tahun 1983 tentang Ketentuan Umum dan Tata Cara Perpajakan pada pasal 1 ayat 1 berbunyi pajak adalah kontribusi wajib kepada Negara yang terutang oleh orang pribadi atau badan yang bersifat memaksa berdasarkan UndangUndang, dengan tidak mendapatkan imbalan secara langsung dan digunakan untuk keperluan Negara bagi sebesar-besarnya kemakmuran rakyat. pajak merupakan iuran dari rakyat kepada Negara yang dapat dipaksakan dan dipungut berdasarkan Undang-Undang dan Wajib Pajak yang melakukan pembayaran iuran kepada Negara dengan tidak mendapatkan balas secara langsung. Pemerintah menggunakan pajak untuk membiayai pengeluaran-pengeluaran yang bermanfaat bagi Negara dan masyarakat luas.

Sebagai sumber pendapatan negara, pajak berfungsi untuk membiayai pengeluaran-pengeluaran negara. Untuk menjalankan tugas-tugas rutin negara dan melaksanakan pembangunan, negara membutuhkan biaya. Biaya ini dapat diperoleh dari penerimaan pajak, hal ini menjadi fungsi pajak sebagai fungsi anggaran. Pemerintah bisa mengatur pertumbuhan ekonomi melalui kebijaksanaan pajak. Dengan fungsi mengatur, pajak bisa digunakan sebagai alat untuk mencapai tujuan. Contohnya dalam rangka menggiring penanaman modal, baik dalam negeri maupun luar negeri, diberikan berbagai macam fasilitas keringanan pajak. Dalam rangka melindungi produksi dalam negeri, pemerintah menetapkan bea masuk yang tinggi untuk produk luar negeri, hal ini menjadi fungsi pajak sebagai fungsi mengatur/regulerend. 
Menurut Awaluddin (2017:2) Pajak sebagai iuran kepada kas negara (peralihan kekayaan dari sektor partikulir ke sektor pemerintah) berdasarkan Undang-Undang (dapat dipaksakan) dengan tiada mendapat jasa timbal (tegen prestasi), yang langsung dapat ditunjukkan dan digunakan untuk membiayai pengeluaran umum.

\section{E-System Perpajakan}

Sistem elektronik dalam pelayanan perpajakan yang di buat oleh Direktorat Jenderal Pajak (DJP) berguna untuk mempermudah Wajib Pajak yaitu e-SPT (Surat Pemberitahuan Elektronik), e-Registration, dan e-Filing. Dengan adanya e-System diharapkan kepada Wajib Pajak untuk dapat mengisi, menghitung, membayar dan melaporkan pajaknya secara mandiri. Dalam era globalisasi pelayanan pajak yang diberikan juga mendukung modernisasi yaitu dalam bentuk pengembangan dan penerapan sistem informasi. Perkembangan yang semakin modern, menuntut pemerintah untuk menciptakan program guna mempermudah wajib pajak dalam melaksanakan tugasnya serta memenuhi kewajiban perpajakannya, sehingga diharapkan dapat memenuhi target penerimaan pajak. Program ini dilaksanakan pemerintah melalui Direktorat Jenderal Pajak dengan melakukan modernisasi perpajakan dengan menggunakan teknologi informasi berbasis e-System (Sistem Elektronik). E-System perpajakan merupakan modernisasi perpajakan dengan tujuan mempermudah wajib pajak untuk melaporkan pajak. (Rahayu 2017:149).

Pemerintah menyediakan aplikasi yang dapat digunakan oleh Wajib Pajak untuk mewujudkan sistem elektronik perpajakan secara modern dalam melakukan pengisian SPT secara cepat, cepat dan akurat. Berdasarkan Peraturan Direktorat Jenderal Pajak Nomor 01/PJ/2016 e-SPT adalah data SPT wajib Pajak dalam bentuk elektronik yang di buat oleh Wajib Pajak dengan menggunakan aplikasi e-SPT yang disediakan oleh DJP. Aplikasi e-SPT adalah aplikasi yang dibuat oleh DJP untuk di gunakan oleh Wajib Pajak dalam melaporkan SPT nya agar lebih mudah dan tidak menghabiskan banyak kertas/paperless. Penggunaan e-SPT dimaksudkan agar semua proses kerja dan pelayanan perpajakan berjalan dengan baik, lancar, akurat serta mempermudah Wajib Pajak dalam melaksanakan kewajiban perpajakannya sehingga kepatuhan wajib pajak di harapkan akan meningkat.

Selain aplikasi, Direktorat Jenderal Pajak juga menerapkan e-Filing sebagai suatu cara penyampaian Surat Pemberitahuan (SPT) secara elektronik yang dilakukan secara online dan real time melalui internet pada website Direktorat Jenderal Pajak (http://www.pajak.go.id) atau Penyedia Layanan SPT Elektronik atau Application Service Provider (ASP). Dengan adanya e-Filing, Wajib Pajak tidak perlu lagi melakukan pencetakan semua formulir laporan dan menunggu tanda terima secara manual. Online berarti bahwa Wajib Pajak dapat melaporkan pajak melalui internet, sedangkan kata realtime berarti bahwa konfirmasi dari Direktorat Jenderal Pajak (DJP) dapat diperoleh saat itu juga apabila data-data Surat Pemberitahuan (SPT) yang diisi dengan lengkap dan benar telah sampai dikirim secara elektronik. (Rahayu, 2017).

Peraturan Direktorat Jenderal Pajak Nomor PER-48/PJ/2011 tentang Perubahan Kedua Atas Peraturan Direktur Jenderal Pajak Nomor Per-19/PJ/2009 Tentang Tata Cara Penerimaan dan Pengolahan Surat Pemberitahuan Tahunan tanggal 30 Desember 2011 yang direvisi kembali dalam Peraturan Dirjen Pajak Nomor PER-02/PJ/2019 tanggal 30 Januari 2019. Peraturan Direktorat Jenderal Pajak Nomor PER-02/PJ/2019 ini bertujuan untuk mencapai transparansi dan bisa menghilangkan praktek-praktek Korupsi, Kolusi dan Nepotisme (KKN), Wajib pajak tidak perlu lagi datang ke Kantor Pelayanan Pajak jika sudah menggunakan fasilitas e-Filing sehingga penyampaian SPT menjadi lebih mudah dan lebih cepat.Hal ini karena pengiriman SPT dapat dilakukan dimana saja dan 
kapan saja serta dikirim langsung ke database Direktorat Jenderal Pajak dengan fasilitas internet yang disalurkan melalui satu atau beberapa perusahaan Penyedia Jasa Aplikasi (ASP) yang ditunjuk oleh Direktorat Jenderal Pajak. e-Filing mempermudah penyampaian SPT dan memberi keyakinan kepada Wajib Pajak bahwa SPT sudah benar diterima Direktorat Jenderal Pajak saat keamanan jauh lebih terjamin.

\section{Kepatuhan Wajib Pajak}

Kondisi perpajakan yang menuntut keikutsertaan aktif Wajib Pajak dalam menyelenggarakan perpajakannya membutuhkan kepatuhan Wajib Pajak yang tinggi, yaitu kepatuhan dalam pemenuhan kewajiban perpajakan yang sesuai dengan kebenarannya. Kepatuhan memenuhi kewajiban perpajakan secara suka rela (Voluntary Of Complience) merupakan inti dari Self Assessment System, dimana Wajib.

Pajak bertanggung jawab menetapkan sendiri kewajiban perpajakan kemudian secara akurat dan tepat waktu dalam membayar dan melaporkan pajaknya. Kepatuhan perpajakan dapat didefinisikan sebagai suatu keadaan dimana Wajib Pajak memenuhi semua kewajiban perpajakan dan melaksanakan hak perpajakannya sesuai ketentuan perundang-undangan perpajakan yang berlaku (Rahayu,2017:358).

Keputusan Menteri Keuangan No.544/KMK.04/2000 menyatakan kepatuhan perpajakan merupakan tindakan Wajib Pajak dalam pemenuhan kewajiban perpajakannya sesuai dengan ketentuan peraturan perundang-undangan dan peraturan pelaksanaan perpajakan yang berlaku dalam suatu Negara. Berdasarkan Keputusan Menteri Keuangan Nomor 74/PMK.03/2012, yang menyatakan bahwa Wajib Pajak dapat ditetapkan sebagai Wajib Pajak patuh apabila memenuhi kriteria yaitu, Tepat waktu dalam menyampaikan Surat Pemberitahuan (SPT), Tidak mempunyai tunggakan pajak untuk semua jenis pajak, kecuali tunggakan pajak yang telah memperoleh izin mengangsur atau menunda pembayaran pajak. Dan tidak pernah dipidana karena melakukan tindak pidana di bidang perpajakan berdasarkan putusan pengadilan yang telah mempunyai kekuatan hukum tetap dalam jangka waktu 5 (lima) tahun terakhir.

\section{METODE PENELITIAN}

Penelitian ini dilakukan di Kantor Pelayanan Pajak (KPP) Pratama Kendari yang berlokasi di Jalan Sao-Sao No. 188, Kelurahan Bende, Kecamatan Kadia, Kota Kendari, Provinsi Sulawesi Tenggara. Sumber data yang digunakan dalam penelitian ini menggunakan data primer dan data sekunder. Data primer diperoleh melalui wawancara dengan pegawai pajak maupun wajib pajaki yang terlibat secara langsung dengan efektifitas e-System di KPP Pratama Kendari Provinsi Sulawesi Tenggara sedangkan data sekunder berasal dari Data Jumlah Wajib Pajak pengguna E-system, dan laporan tingkat persentase pengukuran efektifitas.

Metode Analisis data yang dilakukan dalam penelitian ini yaitu dengan membandingkan data dari 2014-2018 dan juga berdasarkan pernyataan responden melalui kuesioner dengan indikator efektifitas dan kepatuhan perpajakan Untuk mengetahui tingkat efektifitas e-System dalam meningkatkan kepatuhan Wajib Pajak dalam melaporkan SPT Tahunan di KPP Pratama Kendari dengan cara mengidentifikasi pemenuhan indikator untuk 2 indikator tersebut .Metode yang digunakan untuk pengumpulan data dalam penelitian yaitu Kuesioner, wawancara, dan dokumentasi. Kuesioner merupakan teknik pengumpulan data yang dilakukan dengan cara memberi seperangkat pernyataan atau pertanyaan tertulis kepada responden untuk dijawabnya (Sugiyono, 2017: 142). Wawancara digunakan sebagai teknik pengumpulan data apabila ingin melakukan studi untuk menemukan permasalahan yang harus di teliti. Dokumentasi merupakan teknik penelitian dimana mengumpukan data-data yang diperlukan 
Jurnal Akuntansi dan Keuangan (JAK)

Volume 5, Nomor 2 Tahun 2020

Page: 318 - 328

http://ojs.uho.ac.id/index.php/jak-uho

e-ISSN: 2088-4656

sehubungan dengan penelitian misalnya struktur organisasi, tugas dan tanggung jawab, pangkat, dan golongan dan jenis kelamin.

Untuk mengetahui Persentase efektifitas dan kepatuhan berdasarkan jawaban responden terhadap Penggunaan oleh Wajib Pajak Orang Pribadi dalam melaporkan dan mengisi SPT Tahunan menggunakan e-System menggunakan skala Guttman (Riduwan,2013) sebagai berikut :

$$
\text { Persentase }=\longrightarrow \text { X 100\% }
$$

Persentase skor diperoleh selanjutnya dibandingkan dengan kriteria interpretasi skor kuisioner

$\begin{array}{ll}\text { Angka } 81 \%-100 \% & =\text { Sangat Patuh/efektif } \\ \text { Angka 61\%-80\% } & =\text { Patuh/efektif } \\ \text { Angka } 41 \%-60 \% & =\text { Cukup Patuh/efektif } \\ \text { Angka 21\%-40\% } & =\text { Kurang Patuh/efektif } \\ \text { Angka 0\%-20\% } & =\text { Tidak Patuh/efektif }\end{array}$

\section{HASIL PENELITIAN DAN PEMBAHASAN}

\section{Hasil Penelitian}

Data penelitian ini diperoleh dari seluruh responden yang merupakan hasil dari pengisian identitas yang dilakukan oleh 91 responden. rekapitulasi distribusi frekuensi jawaban atas karakteristik wajib pajak non pns pengguna e-system sebagai berikut :

Tabel 4.1 Karakteristik Wajib Pajak Non Pns Pengguna E-System

\begin{tabular}{|c|c|c|c|c|}
\hline No & \multicolumn{2}{|c|}{ Karakteristik Responden } & Jumlah & Persentase \% \\
\hline \multirow{3}{*}{1} & \multirow{3}{*}{ Menurut Jenis Kelamin } & Laki-Laki & 54 & $59 \%$ \\
\hline & & Perempuan & 37 & $41 \%$ \\
\hline & & Total & 91 orang & $100 \%$ \\
\hline \multirow{4}{*}{2} & \multirow{4}{*}{ Menurut Usia } & $21-30$ & 30 & $33 \%$ \\
\hline & & $31-40$ & 34 & $37 \%$ \\
\hline & & $>40$ & 27 & $30 \%$ \\
\hline & & Total & 91 orang & $100 \%$ \\
\hline \multirow{4}{*}{3} & \multirow{4}{*}{$\begin{array}{l}\text { Menurut Tingkat } \\
\text { Pendidikan }\end{array}$} & SMA & 54 & $59 \%$ \\
\hline & & Diploma & 17 & $19 \%$ \\
\hline & & Sarjana & 20 & $22 \%$ \\
\hline & & Total & 91 orang & $100 \%$ \\
\hline \multirow{3}{*}{4} & \multirow{3}{*}{ Menurut Pekerjaan } & Petani & 24 & $26 \%$ \\
\hline & & Wiraswasta & 67 & $74 \%$ \\
\hline & & Total & 91 orang & $100 \%$ \\
\hline \multirow{4}{*}{5} & \multirow{4}{*}{$\begin{array}{l}\text { Menurut masa } \\
\text { penggunaan E-System } \\
\text { berupa e-SPT dan e- } \\
\text { Filing }\end{array}$} & $<1$ Tahun & 32 & $35 \%$ \\
\hline & & 1-3 Tahun & 47 & $52 \%$ \\
\hline & & $>3$ Tahun & 12 & $13 \%$ \\
\hline & & Total & 91 orang & $100 \%$ \\
\hline
\end{tabular}

Sumber:Data Primer Diolah, 2020

Karakteristik responden berdasarkan jenis kelamin pada Tabel 4.2 menunjukkan persentase responden laki-laki sebesar 59\% dengan jumlah 54 orang sedangkan responden perempuan sebesar $41 \%$ dengan jumlah 37 orang. Dapat disimpulkan bahwa responden laki-laki lebih banyak dari responden perempuan. Karakteristik berdasarkan usia menunjukkan bahwa 33\% atau 30 orang responden memiliki usia berkisar 21-30 tahun, $37 \%$ atau 34 orang responden memiliki usia berkisar 31-40 tahun, dan 30\% atau 27 orang

Jurnal Akuntansi dan Keuangan Fakultas Ekonomi dan Bisnis, UHO 
Jurnal Akuntansi dan Keuangan (JAK)

Volume 5, Nomor 2 Tahun 2020

Page: 318 - 328

http://ojs.uho.ac.id/index.php/jak-uho

e-ISSN: 2088-4656

responden memiliki usia lebih dari 40 tahun . Data karakteristik berdasarkan tingkat pendidikan menunjukkan bahwa 54 orang atau 59\% responden memiliki tingkat pendidikan terakhir yaitu SMA, 17 orang atau 19\% responden memiliki tingkat pendidikan terakhir diploma, dan 20 orang atau $22 \%$ responden memiliki tingkat pendidikan terakhir Sarjana. Karakteristik responden berdasarkan pekerjaan menunjukkan bahwa $26 \%$ atau 24 orang responden memiliki pekerjaan sebagai Petani, dan $74 \%$ atau 67 orang responden memiliki pekerjaan sebagai Wiraswasta. Sedangkan karakteristik menurut masa penggunaan e-System dalam kurun waktu kurang dari 1 tahun $(<1$ tahun) adalah sebanyak 32 orang dengan persentase sebesar 35\% responden, yang menggunakan $\mathrm{e}=$ System dalam kurun waktu 1-3 tahun sebanyak 47 orang dengan persentase $52 \%$ responden, dan yang menggunakan e-System dalam kurun waktu lebih dari 3 tahun $(>3$ tahun) sebanyak 12 orang dengan persentase sebesar $13 \%$ responden.

\section{Analisis Efektifitas e-System Perpajakan di Kantor Pelayanan Pajak Pratama Kendari}

Penggunaan E-System perpajakan yang lebih maju pada KPP Pratama Kendari dengan resmi dapat digunakan pada tahun 2012 secara bertahap. E-System perpajakan tentu memiliki sebuah tujuan. Tujuan adanya E-System adalah untuk mempermudah Wajib Pajak dalam memenuhi kewajibannya yaitu menghitung, membayar serta melaporkan pajak terutangnya sehingga kepatuhan Wajib Pajak akan meningkat. Pelaksanaan Self Assestment System sangat membutuhkan peran Wajib Pajak dalam memenuhi hak dan kewajiban perpajakannya secara mandiri. Oleh karena itu Pemerintah dalam hal ini Direktorat Jenderal Pajak menerbitkan Peraturan Dirjen Pajak Nomor PER02/PJ/2019 Tentang tata cara Penyampaian, Penerimaan dan Pengolahan SPT yang menyatakan bahwa aplikasi e-SPT dibuat oleh Dirjen pajak untuk lebih memudahkan Wajib Pajak dalam melaporkan Pajak terutangnya. Berdasarkan hasil analisis data berdasarkan keefektifan e-System di KPP Pratama Kendari pada setiap sub indikator, ditampilkan simpulan perolehan keseluruhan setiap elemen dapat dilihat pada tabel sebagai berikut :

Tabel 4.1

Penentuan Kategori Rata-Rata Pernyataan Responden dilihat dari Efektifitas ESystem Perpajakan

\begin{tabular}{|c|c|c|c|c|c|c|c|c|}
\hline \multirow{3}{*}{ Indikator } & \multicolumn{4}{|c|}{$\begin{array}{c}\text { Frekuensi Jawaban Responden (F) dan } \\
\text { Persentase } \%\end{array}$} & \multirow{3}{*}{$\begin{array}{l}\text { Total } \\
\text { Skor }\end{array}$} & \multirow{3}{*}{$\begin{array}{l}\text { Rata-Rata } \\
\text { Skor }\end{array}$} & \multirow{3}{*}{ Persen } & \multirow{3}{*}{ Kriteria } \\
\hline & \multicolumn{2}{|c|}{ YA (1) } & \multicolumn{2}{|c|}{ TIDAK $(0)$} & & & & \\
\hline & F & $\%$ & $\mathrm{~F}$ & $\%$ & & & & \\
\hline \multicolumn{9}{|c|}{ 1. E-SPT } \\
\hline 1 & 42 & $46 \%$ & 49 & $54 \%$ & 42 & 0,4615 & $46 \%$ & Cukup \\
\hline 2 & 74 & $81 \%$ & 17 & $19 \%$ & 74 & 0,8132 & $81 \%$ & Sangat Efektif \\
\hline 3 & 84 & $92 \%$ & 7 & $8 \%$ & 84 & 0,9231 & $92 \%$ & Sangat Efektif \\
\hline 4 & 74 & $81 \%$ & 17 & $19 \%$ & 74 & 0,8132 & $81 \%$ & Sangat Efektif \\
\hline \multicolumn{5}{|c|}{$\begin{array}{c}\text { Rata-rata Sub Indikator E-SPT di KPP Pratama } \\
\text { Kendari }\end{array}$} & 274 & 3,0111 & $75 \%$ & Efektif \\
\hline \multicolumn{9}{|c|}{ 2. E-FILING } \\
\hline 4 & 84 & $92 \%$ & 7 & $8 \%$ & 84 & 0,9231 & $92 \%$ & Sangat Efektif \\
\hline 5 & 74 & $81 \%$ & 17 & $19 \%$ & 74 & 0,8132 & $81 \%$ & Sangat Efektif \\
\hline 6 & 91 & $100 \%$ & 0 & $0 \%$ & 91 & 1,00 & $100 \%$ & Sangat Efektif \\
\hline 7 & 91 & $100 \%$ & 0 & $0 \%$ & 91 & 1,00 & $100 \%$ & Sangat Efektif \\
\hline \multicolumn{5}{|c|}{$\begin{array}{c}\text { Rata-rata Sub Indikator E-Filing di KPP Pratama } \\
\text { Kendari }\end{array}$} & 340 & 3,7363 & $93 \%$ & Sangat Efektif \\
\hline
\end{tabular}

Sumber:Data Primer Diolah, 2020 
Jurnal Akuntansi dan Keuangan (JAK)

Volume 5, Nomor 2 Tahun 2020

Page: 318 - 328

http://ojs.uho.ac.id/index.php/jak-uho

e-ISSN: 2088-4656

Data diatas menunjukkan Sub indikator tertinggi dari e-SPT adalah pernyataan nomor tiga sebesar 92\% yaitu dengan adanya e-SPT telah mempermudah Wajib Pajak khususnya Wajib Pajak Orang Pribadi Non Karyawan dalam melakukan perhitungan pajaknya. Sedangkan Sub indikator terendah adalah pernyataan nomor satu bahwa Wajib Pajak sebagian besar belum mengetahui tentang peraturan perpajakan mengenai e-SPT sebesar $46 \%$ dikategorikan cukup efektif. Sedangkan e-Filing Sub indikator tertinggi adalah pernyataan nomor tiga dan empat dengan persentase $100 \%$ yaitu dengan adanya eFiling telah mempermudah Wajib Pajak dalam melaporkan SPT Tahunannya dan juga pihak KPP Pratama telah melakukan sosialisasi secara meluas mengenai e-Filing. Dan indikator terendah dengan persentase $81 \%$ adalah penyataan nomor dua yaitu Wajib Pajak masih ada yang belum memahami manfaat, tujuan dan prosedur dari penerapan e-Filing.

\section{E-System untuk Meningkatkan Kepatuhan Wajib Pajak Orang Pribadi Non Karyawan di KPP Pratama Kendari}

E-System perpajakan dibuat oleh pemerintah dalam hal ini Direktorat Jenderal Pajak untuk memudahkan Wajib Pajak dalam mematuhi kewajibannya yaitu sebagaimana penerapan self assessment system yang memerlukan kesadaran Wajib Pajak itu sendiri dalam menghitung, membayar serta melaporkan pajak terutangnya.Berdasarkan hasil analisis data berdasarkan kepatuhan Perpajakan menggunakan e-System di KPP Pratama Kendari pada setiap sub indikator Berdasarkan jawaban responden, ditampilkan simpulan perolehan keseluruhan setiap elemen dapat dilihat pada tabel sebagai berikut :

Tabel 4.6

Penentuan Kategori Rata-Rata Pernyataan Responden dilihat dari Kepatuhan Perpajakan menggunakan E-System

\begin{tabular}{|c|c|c|c|c|c|c|c|c|}
\hline \multirow{3}{*}{ Indikator } & \multicolumn{4}{|c|}{$\begin{array}{c}\text { Frekuensi Jawaban Responden (F) } \\
\text { dan Persentase } \%\end{array}$} & \multirow{3}{*}{$\begin{array}{l}\text { Total } \\
\text { Skor }\end{array}$} & \multirow{3}{*}{$\begin{array}{l}\text { Rata-Rata } \\
\text { Skor }\end{array}$} & \multirow{3}{*}{ Persen } & \multirow{3}{*}{ Kriteria } \\
\hline & \multicolumn{2}{|c|}{ YA (1) } & \multicolumn{2}{|c|}{ TIDAK $(0)$} & & & & \\
\hline & $\mathrm{F}$ & $\%$ & $\mathrm{~F}$ & $\%$ & & & & \\
\hline \multicolumn{9}{|c|}{ 1. KEPATUHAN DALAM MENGHITUNG PAJAK TERUTANG } \\
\hline 1 & 74 & $81 \%$ & 17 & $19 \%$ & 74 & 0,8131 & $81 \%$ & Sangat Patuh \\
\hline 2 & 80 & $87 \%$ & 11 & $13 \%$ & 80 & 0,8791 & $87 \%$ & Sangat Patuh \\
\hline 3 & 84 & $92 \%$ & 7 & $8 \%$ & 84 & 0,9130 & $92 \%$ & Sangat Patuh \\
\hline \multicolumn{5}{|c|}{ Rata-rata Sub Indikator } & 238 & 2,6052 & $87 \%$ & Sangat Patuh \\
\hline \multicolumn{9}{|c|}{ 2. KEPATUHAN DALAM MELAPORKAN SPT TAHUNAN } \\
\hline 4 & 62 & $68 \%$ & 29 & $32 \%$ & 62 & 0,6813 & $68 \%$ & Patuh \\
\hline 5 & 91 & $100 \%$ & 0 & $0 \%$ & 91 & 1,00 & $100 \%$ & Sangat Patuh \\
\hline 6 & 91 & $100 \%$ & 0 & $0 \%$ & 91 & 1,00 & $100 \%$ & Sangat Patuh \\
\hline 7 & 91 & $100 \%$ & 0 & $0 \%$ & 91 & 1,00 & $100 \%$ & Sangat Patuh \\
\hline \multicolumn{5}{|c|}{ Rata-rata Sub Indikator } & 335 & 3,6813 & $92 \%$ & Sangat Patuh \\
\hline
\end{tabular}

Sumber :Data Primer Diolah, 2020

Data diatas menunjukkan bahwa kepatuhan dalam menghitung Pajak terutang menggunakan aplikasi e-SPT sudah dikategorikan Sangat patuh dengan sub indikator tertinggi adalah pertanyaan nomor 3 dengan persentase $92 \%$ yang artinya Wajib Pajak telah menggunakan e-SPT dalam pengisian SPT Tahunannya. Sedangkan Sub indikator terendah adalah pertanyaan nomor 1 dengan persentase sebesar $81 \%$ artinya masih ada Wajib Pajak yang belum mengetahui perhitungan pajak dengan benar.

\section{Pembahasan}

\section{Analisis Efektifitas E-System di Kantor Pelayanan Pajak Pratama Kendari} Efektifitas E-SPT di Kantor Pelayanan Pajak Pratama Kendari

Berdasarkan hasil penyebaran kuesioner yang dilakukan peneliti E-System perpajakan sudah Cukup Efektif dengan rata-rata jawaban untuk indikator e-SPT sebesar 
75\%, yang artinya Wajib Pajak sudah sebagian besar menggunakan aplikasi e-SPT sebagai tempat pengisian SPT Tahunannya, namun dari data menunjukkan bahwa tahun 2014-2018 penerapan e-SPT masih Kurang efektif hal ini dijelaskan oleh Subbagian Umum dan kepatuhan internal Ibu Febiana Kusuma Dewi bahwa "penerapan sistem Elektronik e-SPT di KPP Pratama Kendari dimulai tahun 2012 yang awalnya manual menjadi elektronik dalam pengisian SPT, tentu tidak mudah untuk menyesuaikannya sehingga membutuhkan waktu untuk bisa efektif seperti harus diadakannya sosialisasi,". Kantor Pelayanan Pajak Pratama Kendari selalu mengadakan sosialisasi terkait e-SPT yang dinamai "Pojok Pajak" yang tujuannya agar Wajib Pajak mengetahui serta melaksanakan aplikasi yang diberikan pemerintah dalam mengisi SPT dengan menggunakan media e-SPT.

\section{Efektifitas E-Filing di Kantor Pelayanan Pajak Pratama Kendari}

Hasil penelitian menunjukkan Indikator E-Filing berdasarkan jawaban responden dari pernyataan pertama sampai terakhir dengan rata-rata Jawaban responden termasuk dalam kategori sangat efektif. Hal ini juga didukung dengan data di KPP Pratama Kendari tahun 2014 target penggunaan e-Filing sebesar 76,90\% sudah mulai efektif sehingga pada tahun 2015 sampai dengan tahun 2018 target penggunaan e-Filing sudah termasuk dalam kategori sangat efektif dengan persentase yang meningkat setiap tahunnya. Wajib Pajak menganggap sistem e-filing mudah digunakan dan dioperasionalkan terutama dalam hal mengirim SPT secara online.

Berdasarkan Wawancara di KPP Pratama pada Subbagian Umum dan kepatuhan internal Ibu Febiana Kusuma Dewi bahwa "sebagian besar Wajib Pajak lebih mengetahui penggunaan e-Filing sehingga efektifitas penggunaan dan juga kepatuhan Wajib Pajak lebih meningkat dengan adanya teknologi e-Filing, namun ada pula Wajib Pajak yang tidak mengetahui penggunaan dari sistem elektronik dan kebanyakan Wajib Pajak yang sudah berumur 40 tahun keatas.

\section{E-System Untuk Meningkatkan Kepatuhan Wajib Pajak Orang Pribadi di KPP \\ Pratama Kendari}

Hasil Penelitian menunjukkan bahwa jawaban responden dari dua indikator dengan indikator pertama yaitu kepatuhan dalam menghitung pajak terutang pada pernyataan pertama Wajib pajak sudah patuh dalam menghitung pajak dengan benar namun dibandingkan pada poin kedua dan ketiga jawaban responden lebih tinggi dengan persentase sebesar $87 \%$ dan $92 \%$ yang artinya Wajib Pajak sudah sangat patuh dalam menggunakan Aplikasi e-SPT sebagai tempat perhitungan dan pengisian SPT Tahunan.

\section{KESIMPULAN,IMPLIKASI, KETERBATASAN, DAN REKOMENDASI}

\section{Kesimpulan}

Kesimpulan dari hasil penelitian dan pembahasan yang di kamukakan sebelumnya,adalah sebagai berikut:

1. Efektifitas Penggunaan E-System berupa E-SPT di Kantor Pelayanan Pajak Kota Kendari tahun 2020 sudah dikategorikan Efektif artinya Wajib Pajak sudah melakukan pengisian SPT Tahunan menggunakan aplikasi ini. Sedangkan Efektifitas Penggunaan E-System berupa e-filing dikategorikan Sangat efektif yakni Wajib Pajak sudah menggunakan e-filing sebagai media pelaporan SPT.

2. E-system berupa e-SPT dalam meningkatkan kepatuhan Wajib Pajak berdasarkan data di KPP Pratama Kendari dari tahun 2014-2018 sudah meningkat namun masih dikategorikan Kurang Patuh. Hal ini dikarenakan banyaknya Wajib Pajak terdaftar tidak sebanding dengan Wajib Pajak yang menggunakan e-SPT. Namun tahun 2020 pihak KPP Pratama Kendari tidak lagi melayani pengisian SPT secara manual namun 
Jurnal Akuntansi dan Keuangan (JAK)

Volume 5, Nomor 2 Tahun 2020

Page: 318 - 328

http://ojs.uho.ac.id/index.php/jak-uho

e-ISSN: 2088-4656

harus dengan media e-SPT sehingga tingkat kepatuhan Wajib Pajak dalam Implikasi

menggunakan e-SPT meningkat

E-System berupa e-SPT di Kantor Pelayanan Pajak Pratama Kendari sudah mulai efektif tahun 2020, namun berdasarkan jawaban responden masih banyak Wajib Pajak yang kurang mengerti terhadap penerapan dari sistem ini selain itu banyaknya wajib pajak yang mendaftarkan diri hanya untuk memperoleh NPWP tanpa ada niat untuk membayar serta melaporkan pajak terutangnya sehingga mempengaruhi tingkat kepatuhan.

\section{Keterbatasan}

Penelitian ini telah diusahakan dan dilaksanakan sesuai dengan prosedur, namun demikian masih memiliki keterbatasan. Keterbatasan Penelitian ini masih terbatas pada Indikator yang mempengaruhi tingkat efektifitas dan kepatuhan Wajib Pajak hanya dalam melakukan pengisian serta pelaporan SPT.

\section{Rekomendasi}

Berdasarkan hasil temuan penelitian dan pembahasan mengenai efektifitas eSystem di KPP Pratama Kendari, peneliti mengemukakan saran sebagai berikut :

1. Pihak KPP Pratama Kendari

KPP Pratama Kendari diharapkan untuk memberikan pelayanan dan penyuluhan terkait E-System berupa e-SPT secara lebih baik lagi dan diharapkan selalu memberikan inovasi dan kemudahan penggunaan E-System yang telah diterapkan agar Wajib Pajak dapat menggunakan sistem ini tanpa merasakan kesulitan. Selain itu, diharapkan Pihak KPP Pratama Kendari tidak hanya memberikan pelayanan dan pelatihan untuk para kepala kantor sebagai Wajib Pajak namun juga harus memberikan penyuluhan kepada staf kantor dari wajib Pajak tersebut.

2. Pihak Peneliti Selanjutnya

Peneliti selanjutnya diharapkan untuk memberikan tambahan untuk teori-teori dari indikator yang diteliti dan juga mengembangkan pertanyaan terkait kuesioner dan juga wawancara dari pihak-pihak yang bersangkutan terkait indikator yang diteliti agar mendapatkan hasil yang lebih baik lagi.

\section{DAFTAR PUSTAKA}

Awaluddin, Ishak. 2017. Perpajakan: Pembahasan Sesuai Aturan Pelaksanaan Perpajakan Terbaru 2017. Yogyakarta: K-Media

Direktorat Jenderal Pajak. 2009. Undang-Undang Nomor 16 tahun 2009 tentang Ketentuan Umum dan Tata Cara Perpajakan. (Online), Diakses Pada tanggal 11 September 2019

Direktorat Jenderal Pajak. 2019. Nomor PER-02/PJ. Tata Cara Penyampaian, Penerimaan, dan Pengolahan SPT. (Online) https://www.pajak.go.id/sites/default/files/2019-03/PER02PJ2019DIST2Induk.pdf Diakses pada tanggal 20 Oktober 2019

Ilyas, Wirawan B. 2007. Hukum Pajak. Jakarta: Salemba Empat

Jogiyanto, 2007. Sistem Informasi Keprilakuan. Edisi Revisi. Yogyakarta: Andi

Kementrian Keuangan Republik Indonesia. 2012. Peraturan Menteri Keuangan Nomor 74/PMK.03/2012 tentang Tata Cara Penetapan dan Pencabutan Penetapan Wajib Pajak Dengan Kriteria Tertentu Dalam Rangka Pengembalian Pendahuluan Kelebihan Pembayaran Pajak (Online) https://jdih.kemenkeu.go.id/fulltext/2012/74 PMK.03 2012Per.HTM diakses pada tanggal 20 November 2019 
Jurnal Akuntansi dan Keuangan (JAK)

Volume 5, Nomor 2 Tahun 2020

Page: 318 - 328

http://ojs.uho.ac.id/index.php/jak-uho

e-ISSN: 2088-4656

Mardiasmo. 2016. Perpajakan Edisi Terbaru 2016. Yogyakarta: Penerbit Andi

Rahayu, Siti Kurnia. 2017. Perpajakan Indonesia: Konsep dan Aspek Formal. Bandung: Rekayasa Sains

Sugiyono, 2017. Metode Penelitian Kuantitatif, Kualitatif dan R\&D. Bandung: Alfabeta

Waluyo. (2011). Perpajakan Indonesia. Jakarta: Salemba Empa 